\title{
The Use Of Ohlson's O-Score For Bankruptcy Prediction In Thailand
}

\author{
Judy Ramage Lawrence, Christian Brothers University, USA \\ Surapol Pongsatat, Ramkhamhaeng University, Thailand \\ Howard Lawrence, University of Mississippi, USA
}

\begin{abstract}
Business failure is a major concern to all parties involved and can create high costs and heavy losses. If bankruptcy can be predicted with reasonable accuracy ahead of time, firms can better protect their businesses and can take action to minimize risk and loss of business, and perhaps even prevent the bankruptcy itself. Bankruptcy prediction in thailand is important because business in thailand has historically operated on a system of trust where one person doing business trusts the other to perform as agreed upon in written and oral contracts. The threat of bankruptcy tends to diminish that trust and weakens the country's ability to prosper. While research in bankruptcy has been extensive, there has been only limited research on bankruptcy prediction in thailand. This study expands on an earlier study by pongsatat, et al (1994) using ohlson's o-score to determine if there a significant difference in ohlson's o-score as measured by ohlson's logit analysis model between bankrupt and non-bankrupt firms in thailand. The results of the independent samples t-test demonstrates that there are significant differences in the population means for one year, two years and three years prior to bankruptcy at the 0.05 level. Therefore the null hypothesis that there is no difference in the mean of ohlson's o-score as measured by logit analysis between bankrupt and non-bankrupt firms in thailand is rejected.
\end{abstract}

Keywords: Bankruptcy; Prediction; Ohlson O-Score; Thailand

\section{INTRODUCTION}

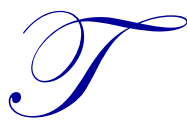

he failure of a business organization has significant economic effects for its owners, creditors, and to society overall. Almost every firm has debt and in the majority of cases that debt is the result of good financial planning, because debt financing is often a lower cost alternative to equity financing. Unfortunately, with debt there comes risk, and the ultimate risk is that of bankruptcy. To avoid this problem firms need reliable ways to predict bankruptcy. This is so because with proper warning, businesses can often take the necessary measures to minimize this risk and possibly prevent the bankruptcy itself.

Thailand is a country that has historically operated on a system of personal trust between parties. Oral contracts are more common in Thailand than in countries such as the United States. Bankruptcy causes that trust to be diminished and ultimately hurts the country's ability to prosper. There have been many studies of bankruptcy in Asia with the majority finding that the causes of bankruptcy in Asian countries can be quite different from studies in western countries (Pongsatat, et al, 2004: Evans, et al, 2013; Sirirattanaphonkun \& Pattarathammas, 2012; Treewichayapong, et al 2011; Reynolds, et al, 2002; Urapeepatanapong, et al, 1998). The analysis of financial ratios has been the primary method used for analysis. (See: Pongsatat, et al, 2004; Clark \& Jung, 2002; Brietzke, 2001; Pugh \& Dehesh, 2001; Haley, 2000; \& Tirapat \& Nittayagasetwat, 1999). Four of these studies addressed bankruptcy in Thailand (Pongsatat, et al, 2004; Evans, et al, 2013; Reynolds, et al, 2002 \& Tirapat \& Nittayagasetwat, 1999). The remaining studies addressed bankruptcy in South Korea (Clark \& Jung, 2002; Haley, 2000) Indonesia (Brietzke, 2001), and Taiwan (Clark \& Jung, 2002). As in the west, financial strength has been the primary indicator of the ability to avoid bankruptcy. Other factors have also come into play, with the inability to adjust to changing environmental factors being the major cause. Such factors as customer preferences, social norms, new legal requirements and rapidly changing global competitive forces have meant that companies must adjust or 
die. As these forces continue, companies must find better ways to predict bankruptcy. This is all the more important in Thailand today given that much of the investment that previously came to Thailand now goes to countries such as China and Vietnam.

Two of the primary methods used in the west to predict bankruptcy are Altman's Z-score and Ohlson's Oscore. Pongsatat, et al, (2004) examined the comparative ability of Ohlson's Logit model and Altman's fourvariance model for predicting bankruptcy in Thailand to determine if there was a difference in their ability to predict bankruptcy in Thailand. This study expands on Pongsatat's 2004 study to specifically examine Ohlson's logit model's ability to predict bankruptcy for both financial and non-financial firms.

Pongsatat's 2004 study found that this analysis is important because evidence suggests that studies conducted in countries such as the united states and the european union may not have relevance to a country such as thailand. Pongsatat cited tirapat and nittayagasetwat (1999) who found that the institutional structure of the financial sector in thailand is characterized as a bank centered financial system, while that of the u.s. is a market based system. For example, tirapat and nittayagasetwat (1999) point out that in thailand, the credits from financial institutions such as commercial banks and finance companies can be five or more times larger than the funds raised from the stock and bond markets. In 1997, at the height of the asian crisis, the amount was 16.7 times higher. These are significantly larger numbers than what could be found in most western economies. Other differences in thailand cited by tirapat and nittayagasetwat (1999) included a higher concentration of shares being held by a few individuals and more shares with large family ownership.

\section{DISCUSSION}

The cause of business failures is a matter that has been discussed and researched at length and it has been a topic of interest for hundreds of years. Throughout these years, ratio analysis has been at the heart of the matter. According to Horrigan (1968), the evolution of ratio analysis came about in approximately $300 \mathrm{BC}$, primarily because of Euclid's analysis of the properties of ratios in Book V of his Elements. Wall (1919) may have been the first to recognize that a relative ratio criteria could be used in place of the more popular absolute ratio criteria. Horrigan (1968) described Wall's Study of Credit Barometrics, as historic "because it was a widely-read overt departure from the customary usage of a single ratio with an absolute criterion" (p. 285-286). According to Horrigan, Wall studied 981 firms and used seven ratios in his analysis. The firms were stratified by industry and geographical areas with nine different subdivisions in each stratum. In doing this, "Wall...had, in effect, popularized the ideas of using many ratios and using empirically determined relative ratio criteria" (Horrigan, 1968, p. 286).

Fitzpatrick (1931) also conducted early research in this area. Fitzpatrick examined 13 ratios to see if they could indicate failure. He examined each ratio individually using a univariate analysis. Unfortunately, Fitzpatrick was not able to show a significant relationship with bankruptcy. Thirty-five years later Beaver (1966a and 1966b) conducted a univariate analysis and was able to show a significant relationship. Beaver's study is considered one of the classics in the field.

Altman (1968) moved from using a univariate approach to using multiple discriminant analysis to predict bankruptcy. Even today, researchers still regard Altman's Z-Score as a good indicator of a company's ability to avoid bankruptcy. Altman later revised his model to incorporate a "four variable Z-Score" prediction model (Altman, 1993). This revised model, Altman felt, significantly improved the predictive ability of his earlier model.

Later, in 1980, Ohlson published a study using "Logit" or Multiple Logistic Regressions in constructing a bankruptcy prediction model. Ohlson felt that his study had an important advantage in that they had an important timing advantage that allowed one to check whether the company entered bankruptcy prior to, or after the date of release for the financials. Ohlson claimed that previous studies did not explicitly consider the timing issue. According to Cybinski (2001), another difference between the early and late studies was that early studies were concerned with explanation rather than prediction. 
In their study of bankruptcy in Thailand, Pongsatat, et al (2004) found that by the end of the 1970s, most bankruptcy prediction used some form of multivariate analysis with multiple discriminant analysis the preferred method. They found also that some researchers felt that multiple discriminant analysis had two fundamental weaknesses. According to Jones (1987) multiple discriminant analysis does not consider prior probabilities and also assumes an equal probability of group membership based on sample proportions. To eliminate these two weaknesses, researchers began to use two additional statistical techniques: multiple logistic regression (or logit analysis) and probit analysis. Kleinbaum \& Klein, (2002) describe logit as a technique based on a cumulative probability function that does not require the independent variables to be normal. Logit puts a weight on each of the variables so that the formula generates a probability of classification putting the weighted groups into one or more separate groups. The probit method is similar to logit except that it uses a nearly identical normal cumulative probability function instead of the logistical cumulative function (Gentry, Newbold and Whitford, 1985). Boritz and Kennedy (1995) described the differences between the two approaches as simply being that the logit model used the cumulative logistic function and probit used the cumulative normal distribution.

In their review of the literature, Pongsatat et al concluded that Martin (1977) probably was the first to conduct a study using logit analysis in bankruptcy prediction. Martin looked at 58 failed Federal Reserve member banks and compared them to a group of non-failed banks. Using 25 financial ratios classified as asset risk, liquidity, capital adequacy and earnings, Martin developed a model that correctly classified failed banks $87 \%$ to $96 \%$ of the time. Pongsatat et al concluded that this ability to accurately predict failed financial firms was important in any analysis of bankruptcy in Thailand.

As stated above, James Ohlson (1980) is acknowledged to be the first researcher to conduct a comprehensive study of bankruptcy using logit analysis. Ohlson felt that the strength of his technique was that it was simple to apply and could be used in a number of different circumstances (Ohlson, 1980). Ohlson did acknowledge that the weakness in his model was that it did not consider the firm's market transaction data.

Ohlson cited three primary problems with prior studies that had been done using the more popular multiple discriminant analysis technique. First he objected to the statistical requirements imposed on the distributional properties of the ratio. Among these requirements were that the variance - covariance relationships of the ratios had to be the same for both groups and that the predictors (ratios) had to be normally distributed. Second, the output to the multiple discriminant analysis is a score, which has little intuitive interpretation. Third, he did not feel that the use of the procedure of matching failed and non - failed firms provided any benefit to an analysis. Ohlson felt that the use of conditional logit analysis essentially avoids all the problems discussed with respect to multiple discriminant analysis (Ohlson, 1980). Ohlson conducted three sets of computations using his logit model. Model one predicted bankruptcy within one year; model two predicted bankruptcy within two years, given that the company did not fail within the subsequent year; and model three predicted bankruptcy within one or two years.

By obtaining data from the Wall Street Journal Index in the Seventies (1970 - 1976), financial information of 105 bankrupt firms, and 2058 non-bankrupt firms were obtained from the Compustat file. From Ohlson's study the results indicate that the four factors derived from financial statements that are statistically significant for purposes of assessing the probability of bankruptcy are first, size; second, a measure of leverage (total liabilities to total assets); third, a measure of performance (net income to total assets and fixed assets to total liabilities); and fourth, some measures of current liquidity (working capital to total assets, current assets to current liabilities). (Ohlson, 1980)

By the end of his study Ohlson concluded that the predictive power of the model depends upon when the financial report is made available, and the predictive powers seem to be robust across the estimation procedure. Finally, Ohlson recommended that further research needed to be conducted to improve the accuracy of the prediction model. While Ohlson's results were not as good as Altman's, he concluded that his methodology was more sound. He also reached another interesting conclusion from his study in that he found that the size of the firm was the most important predictor in his model (Patterson, 2001). According to Khunthong (1997), Ohlson's model for predicting bankruptcy within one year, using nine accounting ratios and a cutoff point equally weighted with type I and type II errors, gave a correct classification $96 \%$ of the time. 
A review of the literature indicates that it was the Thai Baht crises and the resultant increase in bankruptcies that may have caused researchers to begin to investigate the use of bankruptcy prediction models in Thailand. The financial crisis occurred when banks and financial companies borrowed heavily on a short-term basis from banks in other countries - primarily Japan and the United States - and made overly risky loans to finance the construction of commercial and residential units. When the demand for such units was not forthcoming as expected, a domino effect occurred: the real estate investors who borrowed defaulted, their lenders defaulted, and the banks were left with foreign currency denominated loans requiring payment. A subsequent foreign exchange crisis followed the collapse of the real estate market.

Treewichayapong, et al (2011) conducted a study on real estate bankruptcy in Thailand and found that the results of the bankruptcy prediction using binary logistic regression and Cox proportional hazards model show that financial ratios, as leading indicators of corporate bankruptcy, play more significant roles than company specific and corporate variables. Reynolds et al (2002) examined the financial capital structure of major financial companies in Thailand over the period 1993 - 1998. Their stated purpose was to estimate the probability of a financial company surviving in 1997 when the Thailand financial crisis began. The prediction model applied both probit and logistic binomial regression analyses to estimate the probability of financial distress (defined by Reynolds et al as firms closed down or reorganized) for firms traded on the Stock Exchange of Thailand. The financial data was obtained from balance sheet and income statements for 91 financial companies over the period 1993 to 1996.

Tirapat and Nittayagasetwat (1999) used a logit regression to develop a macro-related micro-crises investigation model for the 459 firms listed in the Stock Exchange of Thailand (SET) in 1996. Fifty-five of these firms were financially distressed under the definition used by the SET. Tirapat and Nittayagasetwat's sample included 341 of the 404 non-failed firms and all 55 of the failed firms. Tirapat and Nittayagasetwat used the SET's definition of a failed firm. This definition says that a firm is distressed when it is either closed down by the Thai government or required by the stock exchange or the Bank of Thailand to submit a restructuring plans.

In their logit regression, Tirapat and Nittayagasetwat (1999) incorporated a two-step process whereby "changes in macroeconomic factors and the firm's sensitivity to those factors affect the firm's stock return, with a firm's stock return in turn having an effect on the firm's probability of financial distress" (p.106). The total prediction accuracy of the Tirapat and Nittayagasetwat model equaled $63.89 \%$ for the full-sample test, $77.49 \%$ for the in-sample test, and $75.76 \%$ for the out-sample test. The results of their study suggest that a firm with a higher estimated rate of return has a lower probability of financial distress. Their study also indicates the importance of macroeconomic conditions because they can strongly influence the probability of a firm's financial distress. The researchers found that the only significant macro factor was the sensitivity of the firm to inflation. In summary, they concluded that only the systematic risk of a firm exposed to inflation affects the probability of the firm's financial distress. The higher a firm's sensitivity to inflation, the more likely the firm's exposure to financial distress. Ohlson's model has been used in a variety of scenarios other than bankruptcy. For example, Lee et al. (2014) evaluated the predictive power of the Ohlson model for future market value assessment. Noga and Schnader, (2013) expanded on Ohlson's model by investigating the association between abnormal changes in book-tax differences (BTDs) and bankruptcy using a hazard model and out-of-sample testing.

\section{RESEARCH METHODOLOGY}

This study uses the logit analysis technique as popularized by Ohlson. Ohlson used this method to develop his "O-score" to be used as a model. There are a variety of reasons for selecting Ohlson's model for this study. Some researchers feel that multiple discriminant analysis has two fundamental weaknesses. As stated earlier, according to Jones (1987) multiple discriminant analysis does not consider prior probabilities and also must assume an equal probability of group membership based on sample proportions. Ohlson (1980) argues that these statistical requirements on the distributional properties of the predictors cause significant problems. For example, Ohlson, states that the requirement of a normally distributed predictor argues against the use of a dummy variable. This limitation, according to Ohlson, severely limits the model as a discriminating tool. Logit analysis, it is argued, eliminates these two weaknesses. 
Other researchers have agreed with Ohlson stating that because logit analysis is based on a cumulative probability function it does not require the independent variables to be normal. Logit puts a weight on each of the variables so that the formula generates a probability of classification putting the weighted groups into one or more separate groups.

Still another argument for logit analysis in this study is that the SET in Thailand has a significant number of financial firms, some of which have faced financial distress. There is some indication that multiple discriminant analysis does not provide a good prediction for financial firms. Pastena and Ruland (1986) used multiple discriminant analysis in their study but stated that they, "restricted the sample to manufacturing firms since the Altman model was not developed for banks, insurance companies, or other nonmanufacturing businesses" (p. 294). Other researchers have come to similar conclusions. Dietrich and Kaplan (1982), for example, stated that probit analysis was theoretically superior to multiple discriminant analysis in their study of bank loans. The elimination of financial institutions is not a restriction that would be possible in this study.

Still another question to address is whether to use the logit or probit method. The probit method is similar to logit except that it uses a nearly identical normal cumulative probability function instead of the logistical cumulative function (Gentry, Newbold and Whitford, 1985). Boritz and Kennedy (1995) described the differences between the two approaches as simply being that the logit model used the cumulative logistic function and probit used the cumulative normal distribution. Because the logit method has been more thoroughly tested and because it is the method used by Ohlson in developing his model, this study uses the logit approach.

\section{Research Question}

The following research question investigates the research problem of this study:

Is there a significant difference in ohlson's o-score as measured by ohlson's logit analysis model between bankrupt and non-bankrupt firms in thailand?

The literature discloses only a few studies of bankruptcy in thailand, which were primarily motivated by the 1997 thai baht crisis that caused thailand to experience a number of bankruptcies. The research in thailand on this subject is so narrow that there is not broad agreement on what factors accurately predict bankruptcy and there is a divergence of conclusions reached. The answer to this research question may help to reconcile some of the past disagreements.

\section{Hypothesis Development}

The research question stated above gives rise to and forms the basis for the following hypothesis.

H1: There is no difference in the mean of ohlson's o score as measured by ohlson's logit analysis between bankrupt and non-bankrupt firms in Thailand.

The dependent variables in this study are defined as failed or non-failed firms in Thailand as identified by the Stock Exchange of Thailand or the Bank of Thailand. The dependent variables will be coded as "0" for a nonfailed firm and " 1 " for a failed firm. This methodology is consistent with the approach used by Ohlson (1980). Independent variables consist of the financial ratios used by Ohlson. They are:

Size $=\log$ of the total assets $/ \log$ of GNP price level index

TLTA $=$ Total liabilities $/$ total assets

WCTA $=$ Working capital $/$ total assets

CLCA $=$ Current liabilities / current assets

NITA $=$ Net income $/$ total assets

FUTL $=$ Cash flows from operation / total liabilities (Note that Ohlson used "funds from operations" as that was the reporting method of the day. Currently, cash flow from operations is the approximately equivalent figure for funds. Accordingly, this study uses cash flows from operations as a proxy for funds from operations.) 
Dummy variables will be used to adjust for certain microeconomic variables. The dummy variables are:

OENEG $=1$, if net income was negative for the last two years $=0$, otherwise.

INTWO $=1$, if total liabilities is greater than total assets $=0$, otherwise.

Changes in net income will be accounted for by using the following variable:

CHIN $=\left(\mathrm{NI}_{t}-\mathrm{NI}_{\mathrm{t}-1}\right)$ divided by $\left(\left|\mathrm{NI}_{t}\right|+\left|\mathrm{NI}_{\mathrm{t}-1}\right|\right)$ where $\mathrm{NI}_{\mathrm{t}}$ is net income for the most recent period. The $(\mid)$ symbol indicates that the absolute value of the variable is to be used.

While other researchers have examined the effect of different variables (see Khodadadi et al. 2013), the financial statement variables used above are the same as those used by Ohlson (1980) in the development of his Oscore. Ohlson stated that "common sense" suggests that the sign of the coefficients would be as follows:

\begin{tabular}{lccc}
\hline & Positive & Negative & Indeterminate \\
\hline TLTA & SIZE & OENIG \\
CLCA & WCTA & \\
INTWO & NITA & \\
& FUTL & \\
& CHIN & \\
\hline
\end{tabular}

As stated above, this study uses logit analysis to compare the failed and non-failed firms. Logit analysis is a member of the general class of models called log-linear models and can be used in a variety of circumstances to deal with any number of outcome variables (Simonoff, 1997). However, in this study, logit is used to perform a logistic regression in which a two-value (binary) outcome is predicted by a variety of variables. In the literature, logit is described as a variation of ordinary regression and is used most frequently to model the relationship between two outcome variables and a set of explanatory variables. While the outcome variables in this study are failed and non-failed firms, the outcome variable could be any dichotomous variable such as "dead" or "alive" in medicine, or "sell" or "don't sell" in investing (Dorak, 2002). The usual goal of logit analysis is to focus on group membership. As stated earlier, logit analysis makes no assumptions about such things as normality or linear relationships. Furthermore, equal variances and the distribution of the predictor variables are not issues to be considered. These advantages are somewhat offset by the fact that the regression is sensitive to extreme variables in the predictor variables and collinearity (Kleinbaum, \& Klein, 2002). Because of this sensitivity, this study takes extreme care in the pre-screening of the predictor variables.

Logit analysis depends heavily on probability. Because this study uses matched pair samples with an equal number of failed and non-failed firms, the probability of randomly selecting a failed firm is $50 \%$ or 0.5 . To illustrate further, in a similar way, the probability of rolling a "six" on a single roll of a die would be 1/6 or 0.16667 .

In a logistic regression, the "odds" of an event is defined as the probability of an event occurring, divided by the probability of the event not occurring. The probability of not rolling a six on a roll of a die would be $1-p(X)$ or 0.8333 . The odds, therefore, would be the 0.16667 divided by 0.8333 or 0.2 . The odds ratio for a predictor tells the relative amount by which the odds of the outcome increase or decrease when the value of the predictor is increased by one unit. One of the fundamental rules in probability analysis is that probabilities cannot exceed one. Note, however, that while the probabilities cannot exceed one, the odds can be greater than one. It is in the creation of the odds that the "logit" comes into play. The logit is the natural logarithm of the odds. Accordingly, the logit of rolling a six would be the natural log of 0.2 or a minus 1.609 (Kleinbaum, \& Klein, 2002).

Recall from above that Ohlson's logistic regression model was given as:

$$
\mathrm{P}(\mathrm{B})=1 / 1+\mathrm{e}^{-\mathrm{z}}
$$

This formula is the logistical regression that was run to address the research question in the study. The three major results from this analysis consist of two primary elements. The first is a classification table that identifies the correct and incorrect classifications identified by the model. The second measurement seeks to obtain an indication of how well the data fits the model. Indicators of this fit include the statistical significance for each variable in the equation as well as a Chi-square statistic for each variable. The overall measure of the fit of the model considers the log-likelihood statistic along with an appropriate goodness of fit statistic $\left(\mathrm{R}^{2}\right)$. 


\section{Description of Population and Sample}

Similar to Pongsatat et al. (2004) the population of this study is the firms listed on the Stock Exchange of Thailand. From this population, a sample was selected of 60 failed or financially distressed firms and 60 non-failed firms. A failed firm or financially distressed firm is one that either: (1) has been liquidated during the current year, (2) has received an audit that expresses concern about the going concern capabilities of the firm, (3) has been closed down by governmental authorities, (4) has been asked to submit restructuring plans by the Bank of Thailand or the Stock Exchange of Thailand or (5) has filed bankruptcy proceedings in one or more countries or some other notification indicating bankruptcy proceedings. To be selected for study, all firms must have been in business and published financial statements for each of the three years prior to failure. Financial information, including all financial statements was drawn from the e-library of the Stock Exchange of Thailand. Additional information for specific companies were drawn from the annual reports of those firms. Each of the 60 failed and non-failed firms were matched using their SIC code and their asset size.

\section{RESULTS}

The results from this study were obtained from the financial statements of the 60 failed and the 60 nonfailed companies examined. $\mathrm{HO}_{1}$ seeks to determine for both bankrupt and nonbankrupt firms whether there is a significant difference in the mean scores for the two types of firms. Tests were conducted at the 0.05 significance level. The testing purpose was to conclude if the models classification produced statistical significance in the comparison of mean Ohlson's $\mathrm{O}$ scores. The hypothesis for test of significance difference in the mean Ohlson's $\mathrm{O}$ score took the following form:

$$
\text { Where } \begin{aligned}
& \mathrm{H}_{0}: \mu_{\mathrm{B}}=\mu_{\mathrm{NB}} \\
& \mathrm{H}_{\mathrm{A}}: \mu_{\mathrm{B}} \neq \mu_{\mathrm{NB}} \\
& \\
& \mu=\text { Population Mean } \\
& \mathrm{B}=\text { Bankrupt } \\
& \mathrm{NB}=\text { Nonbankrupt }
\end{aligned}
$$

The results of the comparison of the means test for bankrupt and nonbankrupt firms are shown in Table 1 .

Table 1. Comparison of Means between Bankrupt and Nonbankrupt companies using Ohlson's O-Score

\begin{tabular}{lccc}
\hline \multicolumn{1}{c}{ Classification } & Year 1 & Year 2 & Year 3 \\
\hline Bankrupt & 862.7053 & 1302.1660 & 644.3152 \\
Nonbankrupt & 745.0403 & -291.5186 & 169.7120 \\
\hline
\end{tabular}

The statistical characteristics (an independent sample T-test) of Ohlson's Z-score for bankrupt and nonbankrupt firms are shown in Tables 2 and 3 and 4. 
Table 2. Statistical Characteristics of the Ohlson's O- Score: t-test year one prior to bankruptcy.

\begin{tabular}{cccccc}
\hline & & \multicolumn{4}{c}{ Group Statistics } \\
\hline & Firm y1 & N & Mean & Std. Deviation & Std. Error Mean \\
\hline O score 1 & 1.00 & 58 & 862.7053 & 1639.39957 & 215.26371 \\
& 2.00 & 62 & -745.0403 & 3065.64952 & 389.33788 \\
\hline
\end{tabular}

\begin{tabular}{|c|c|c|c|c|c|c|c|c|c|c|}
\hline \multicolumn{11}{|c|}{ Independent Samples Test } \\
\hline & & \multicolumn{2}{|c|}{$\begin{array}{c}\text { Levene's Test for } \\
\text { Equality of } \\
\text { Variances } \\
\end{array}$} & \multicolumn{7}{|c|}{ t-test for Equality of Means } \\
\hline & & \multirow[t]{2}{*}{$\mathbf{F}$} & \multirow{2}{*}{ Sig. } & \multirow{2}{*}{$\mathbf{t}$} & \multirow[t]{2}{*}{ df } & \multirow{2}{*}{$\begin{array}{c}\text { Sig. } \\
\text { (2-tailed) }\end{array}$} & \multirow{2}{*}{$\begin{array}{c}\text { Mean } \\
\text { Difference }\end{array}$} & \multirow{2}{*}{$\begin{array}{l}\text { Std. Error } \\
\text { Difference }\end{array}$} & \multicolumn{2}{|c|}{$\begin{array}{c}\text { 95\% Confidence } \\
\text { Interval of the } \\
\text { Difference } \\
\end{array}$} \\
\hline & & & & & & & & & 8.5 & Upper \\
\hline \multirow[t]{2}{*}{ O score1 } & $\begin{array}{l}\text { Equal variances } \\
\text { assumed }\end{array}$ & .001 & .975 & 3.547 & 118 & .001 & 1607.74567 & 453.26614 & 710.15530 & 2505.33603 \\
\hline & $\begin{array}{l}\text { Equal variances } \\
\text { not assumed }\end{array}$ & & & 3.614 & 94.540 & .000 & 1607.74567 & 444.88476 & 724.48238 & 2491.00895 \\
\hline
\end{tabular}

Table 3. Statistical Characteristics of the Ohlson's O- Score: t-test two years prior to bankruptcy

\begin{tabular}{ccccccc}
\hline & & \multicolumn{2}{c}{ Group Statistics } \\
\hline & Firm y2 & & N & Mean & Std. Deviation & Std. Error Mean \\
\hline Oscore2 & 1.00 & 57 & 1302.1660 & 2182.36311 & 289.06106 \\
& 2.00 & 63 & -291.5186 & 805.87477 & 101.53068 \\
\hline
\end{tabular}

\begin{tabular}{|c|c|c|c|c|c|c|c|c|c|c|}
\hline \multicolumn{11}{|c|}{ Independent Samples Test } \\
\hline & & \multicolumn{2}{|c|}{$\begin{array}{c}\text { Levene's Test for } \\
\text { Equality of } \\
\text { Variances } \\
\end{array}$} & \multicolumn{7}{|c|}{ t-test for Equality of Means } \\
\hline & & \multirow[t]{2}{*}{$\mathbf{F}$} & \multirow{2}{*}{ Sig. } & \multirow[t]{2}{*}{$\mathbf{t}$} & \multirow{2}{*}{ df } & \multirow{2}{*}{$\begin{array}{c}\text { Sig. } \\
\text { (2-tailed) }\end{array}$} & \multirow{2}{*}{$\begin{array}{c}\text { Mean } \\
\text { Difference }\end{array}$} & \multirow{2}{*}{$\begin{array}{l}\text { Std. Error } \\
\text { Difference }\end{array}$} & \multicolumn{2}{|c|}{$\begin{array}{l}\text { 95\% Confidence } \\
\text { Interval of the } \\
\text { Difference } \\
\end{array}$} \\
\hline & & & & & & & & & Lower & Upper \\
\hline \multirow[t]{2}{*}{ Oscore2 } & $\begin{array}{l}\text { Equal variances } \\
\text { assumed }\end{array}$ & 31.492 & .000 & 5.405 & 118 & .000 & 1593.68454 & $\begin{array}{c}294.8455 \\
4\end{array}$ & $\begin{array}{c}1009.810 \\
10\end{array}$ & $\begin{array}{c}2177.558 \\
97\end{array}$ \\
\hline & $\begin{array}{l}\text { Equal variances } \\
\text { not assumed }\end{array}$ & & & 5.202 & $\begin{array}{c}69.71 \\
2\end{array}$ & .000 & 1593.68454 & $\begin{array}{c}306.3735 \\
8\end{array}$ & $\begin{array}{c}982.5972 \\
5\end{array}$ & $\begin{array}{c}2204.771 \\
82\end{array}$ \\
\hline
\end{tabular}

Note: The results of the Independent Samples T-Test demonstrates that there are significant differences in the population means for one year, two years and three years prior to bankruptcy at the 0.05 level. Therefore, the null hypothesis is rejected.

\section{Limitations}

This study was limited to business firms trading on the SET. Thus, the study cannot be generalized to other companies not listed on the SET.

This study focused on the application of Ohlson's logit model A variety of other models are available for predicting bankruptcy such as multiple discriminant analysis, neural networks, and recursive partitioning algorithms. The use of one of these other methods could have arrived at different results. 


\section{Implications of the Research}

Many companies all over the world enter financial distress for a variety of reasons including poor management, dishonest management, economic recession, changes in globalization, and even war and terrorism. Major bankruptcies such as Enron, WorldCom, and Waste Management have caused tens of thousands of employees to lose their jobs, and a greater number of investors to lose their savings. Bankers and creditors lost billions of dollars; communities lost vital services, and the economy of the country suffered. Much of these losses could have been avoided with a suitable early warning system that identified weaknesses and allowed the constituents to make adequate plans and take necessary steps.

\section{Recommendations for Future Research}

Because of the limited focus of this study, it would be helpful for future research to apply similar bankruptcy prediction models to business firms not publicly traded on the Stock Market of Thailand.

Because of the high level of Type $\alpha$ errors in this study, future research should examine other bankruptcy models to determine if a lower level of Type $\alpha$ errors can be realized.

Given the low incidence of research in the area of civil service and government enterprise areas, it is suggested that these areas be examined in future research to identify better when these areas are in danger of failure.

\section{AUTHOR INFORMATION}

Dr. Judy Ramage Lawrence is Professor of Accounting at Christian Brothers University. She holds a BS from the University of Memphis, an MS from the University of Arkansas, and a DBA from Nova Southeastern University. She has over years' experience in accounting in both local and Big Four accounting firms. Her research interest are in the areas of fraud examination and international accounting. Dr. Lawrence has over 30 publications in refereed journals

Dr. Surapol Pongsatat is a lecturer in the Advanced MBA program at Ramkhamhaeng University in Bangkok, Thailand. Dr. Pongsatat is also an advisor in the DPA program at Phetchabun Rajabhat University in the Mueang Phetchabun District, Phetchabun, Thailand. Dr. Pongsat's current research interests are in the field of international business and bankruptcy.

Dr. Howard Lawrence is Clinical Professor of Accounting at The University of Mississippi. He holds a BS in Mechanical Engineering from Christian Brothers University, an MBA from the University of Memphis, and a PhD from the University of Mississippi. Dr. Lawrence has over 20 years' experience in the paper industry and the steel industry. His research interest are in the area of international accounting and fraud examination.

\section{REFERENCES}

Altman, E. I. (1968). Financial ratios, discriminant analysis and the prediction of corporate bankruptcy. Papers and proceedings of the Twenty-Ninth Annual Meeting of the American Finance Association, Detroit, Michigan December 28-30, The Journal of Finance, 23(4), 589-609.

Altman, E. I. (1993). Corporate Financial Distress and Bankruptcy: A Complete Guide to Predicting and Avoiding Distress and Profiting from Bankruptcy, $2^{\text {nd }}$ Ed. New York: John Wiley and Sons.

Beaver, W. H. (1966a). Financial ratios as predictors of failure. Empirical Research in Accounting: Selected Studies, 71-111.

Beaver, W. H. (1966b). Market prices, financial ratios, and the prediction of failure. Journal of Accounting Research, 6(2), 179-182.

Boritz, J. E, \& Kennedy, D. B. (1995). Effectiveness of neural network types for prediction of business failure. Expert Systems with Applications, 9(4), 503-512.

Brietzke, P. (2001). Securitization and bankruptcy in Indonesia: Theme and variations. Global Jurist Topics, 1(1), 516. 
Clark, C. \& Jung, C. (2002). Implications of the Asian flu for developmental state theory: The cases of South Korea and Taiwan. Asian Affairs, an American Review, 29(1), 16-44.

Cybinski, P. (2001). Description, explanation, prediction - the evolution of bankruptcy. Managerial Finance, Patrington: 27(4), 29-46.

Dietrich, R., \& Kaplan, R. (1982). Empirical analysis of the commercial loan classification decision. The Accounting Review, 57(1), 18-38.

Dorak, M. T. (2002). Common concepts in statistics. Common Concepts in Statistics, Glasgow: 10(1), pp. 1-21.

Evans, R.T., Thanida, C., \& Theo, C. (2013). Successful turnaround strategy, Thailand evidence. Journal of Accounting in Emerging Economics. 3(2), 115-124.

Fitzpatrick, P. J. (1931). Symptoms of industrial failures. Catholic University of America Press.

Gentry, J. A., Newbold, P. \& Whitford, D. T. (1985). Classifying bankrupt firms with funds flow components. Journal of Accounting Research, Chicago: 23(1), 146-161.

Haley, U. C. V. (2000). Corporate Governance and restructuring in East Asia: An overview. Seoul Journal of Economics, 13(3), 265-288.

Horrigan, J. O. (1968). A short history of financial ratio analysis. The Accounting Review, 43(2), $284-294$.

Jones, F. L. (1987). Current techniques in bankruptcy prediction. Journal of Accounting Literature, 6(1), 131-164.

Khodadadi, V., Farazmand, H., \& Sheybeh, S. (2013). Assessing the Valuation Model Based on Abnormal Earnings (Ohlson) by Notice to the Macroeconomic Variables. Journal of Financial Accounting Research, 5(17), 321.

Khunthong, J. (1997). Red flags on financial failure: The case of Thai corporation. Unpublished doctoral dissertation, The National Institute of Development Administration, Bangkok.

Kleinbaum, D. G., \& Klein, M. (2002). Logistic Regression: A self-learning text. Springer-Vertag Publishing, $2^{\text {nd }}$ edition, $513 \mathrm{pp}$.

Lee, S., Chen, J., \& Tsai, M. (2014). An Empirical Investigation of the Ohlson Model-A Panel Cointergration Approach. Australasian Accounting Business \& Finance Journal. 8(2), 35-51.

Luther, R. K. (1998). An artificial neural network approach to predicting the outcome of Chapter 11 bankruptcy. The Journal of Business and Economic Studies, Oakdale: 4(1), 57-74.

Martin, D. (1977). Early warning of bank failure: A logit regression approach. Journal of Banking and Finance, $7(1), 249-276$.

Noga, T. J., \& Schnader, A. L. (Sep. 2013). Book-Tax Differences as an Indicator of Financial Distress. Accounting Horizons, 27(3), 469-489.

Ohlson, J. A. (1980). Financial ratios and the probabilistic prediction of bankruptcy. Journal of Accounting Research, New York: 18(1), 109-131.

Pastena, V. \& Ruland, W. (1986). The merger/bankruptcy alternative. The Accounting Review, 59(2), $288-301$.

Patterson, D. W. (2001). Bankruptcy Prediction: A model for The Casino Industry. Unpublished doctoral dissertation, University of Nevada, Las Vegas.

Pongsatat, S., Ramage, J. \& Lawrence, H. (2004). Bankruptcy Prediction for Large and Small Firms in Asia: A Comparison of Ohlson and Altman. Journal of Accounting and Corporate Governance. 1(2). 1-13.

Pugh, C., \& Dehesh, A. (2001). Theory and explanation in international property cycles since 1980. Property Management, Bradford: 19(4). 265-298.

Reynolds, S., Fowles, R., Gander, J., Hunaporntham, W. \& Ratanakomut, S. (2002). Forecasting the probability of failure of Thailand's financial companies in the Asian financial crises. Economic Development and Cultural Change, Chicago, 51(1), 237-47.

Simonoff, J. S. (1997). An unusual episode. Journal of Statistics Education, 5(1), 1-10.

Sirirattanaphonkun, W., \& Pattarathammas, S. (Dec. 2012). Default Prediction for Small-Medium Enterprises in Emerging Markets: Evidence from Thailand. Seoul Journal of Business, 18(2), 25-54.

Tirapat, S. \& Nittayagasetwat, A. (1999). An investigation of Thai listed firms' financial distress using macro and micro variables. Multinational Finance Journal, Camden: 3(2), 103-126.

Treewichayapong, S., Chunhachinda, P., \& Padungsaksawasdi, C. (2011). Bankruptcy Prediction of Real Estate Firms in Thailand. International Journal of Finance, 23(1), 6672-6691.

Urapeepatanapong, K., Sethsathira, S. \& Okanurak, C. (1998). New bankruptcy act to boost Thai economy. International Financial Review, London: 17(4), 33-41.

Wall, A. (1919). A Study of Credit Barometrics. Federal Reserve Bulletin, March, 229-243. 